\title{
Book Review: The Treatise on the Whole-World by Édouard Glissant
}

Heather Alberro (Corresponding author)

Nottingham Trent University, UK

Email: heather.alberro@ntu.ac.uk

Received: $27 / 08 / 2020$

Accepted: 10/10/2020

Published: 01/11/2020

Volume: 1 Issue: 4

How to cite this paper: Alberro, H. (2020). Book Review: The Treatise on the Whole-World

by Édouard Glissant. Journal of Critical Studies in Language and Literature, 1(4), 55-56

DOI: https://doi.org/10.46809/jcsll.v1i4.43

Copyright ( 2020 by author(s) and Global Talent Academy Ltd. This work is licensed under the Creative Commons Attribution International License (CC BY 4.0).

http://creativecommons.org/licenses/by/4.0/

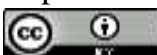

This engaging and challenging work by the seminal French-Caribbean writer and philosopher Édouard Glissant features a timely plea for valuing and preserving diversity, relation and the irreducible alterity of the 'Other'. The book is especially pertinent amidst a historical backdrop plagued by socio-ecological upheavals and the mounting absence of diversity in a multiplicity of forms- from languages to species- which Glissant frequently laments (p. 131). The book's fragmented structure, which may pose a challenge for some readers, features a mosaic of theoretical discussions, poetry and passages narrated by characters from Glissant's previous novels. Yet the book's structure reflects not only Glissant's eclectic background but also the work's core themes of diversity and relation. An array of thinkers, concepts, lines of inquiry and propositions are brought together- albeit not always as clearly or explicitly as they might have been- to produce the whole-text that is The Treatise on the Whole-World.

Glissant spends some time critically reflecting on the "unstoppable flux" of modern technological progress (p. 107) and its wider cultural, social and political implications. For Glissant, technological progress (i.e. the internet) has expanded access to a world of information and has aided the 'creolization' - or unpredictable hybridization of cultures and languages- through time. Creolization, one of his key concepts, has in turn rendered physical frontiers between nations "permeable to cultural and intellectual exchanges, to the hybridization of sensibilities, which has meant that the nationstate is no longer powerful enough to barricade from the inside everyone's relation to the earth" (p. 119). However, technological progress, a tool historically deployed by the Colonial West, still tends to exclude the 'voices of the destitute' (p. 103). He goes on to suggest that the 'Chaos-World' produced by clashes and entanglements between cultures constitutes one of the defining political issues of our time. However, one could argue that global capitalism's profit-driven expansion and exploitation of nature, people and places constitutes a more urgent threat to relation and diversity, as Glissant himself occasionally acknowledges (p.59).

The work in particular and Glissant's writings more generally are strongly influenced by his first-hand experiences with the brutal legacy of colonialism, having been born and raised on the island of Martinique, a French colonial outpost. Thus, the work is populated by postmodern themes such as a rejection of 'totalizing generalizations' and hegemonic universals (Tampio 2009), drawing in particular on the work of Gilles Deleuze in order to promote what he terms a 'poetics of relation'. Here he borrows from Deleuze \& Guattari's (1988) concept of the 'rhizome' which denotes a constellation or assemblage of singularities. Think of mycorrhizal networks, for instance, which are underground networks of fungi that connect individual plants together and constitute a larger, dynamic ecosystem. Glissant similarly sees the 'Whole-World' or the totality that comprises 'the real' as a "body of meanderings wherein life throbs in every corner-and which is forever weaving itself" (p. 78-9). What makes up our Whole-World is an always-developing rhizome of particular places, peoples, languages, and the visions that we have of this totality. Relation is an indispensable aspect 
of our existence and the nature of the Whole-World, to the extent that we are no longer able to sing, speak or work based on our place alone..." (p. 108).

Glissant is deeply critical of what he refers to as the 'single root identity' propagated by Western Hegemonic thought, which excludes and seeks to oppress and/or exploit the 'Other'. Contemporary manifestations of this 'single root' identity can be seen, for instance, in the rise of right-wing populist movements and politics fanning nationalistic fervour and antiimmigration sentiments. Glissant emphasizes the need to shift towards a rhizomic identity predicated on relation and an 'opening up' to the unpredictability and immeasurability of the world and the 'other'. Another key concept of his, 'opacity', denotes the irreducible singularity of the 'other'. That is, one cannot- and should not attempt- to fully know the other at the risk of smothering their difference. Rather, the other in all of their diversity should be celebrated. Therefore, a rhizomic identity entails a shift from a universal and detached 'Being' that 'asserts itself' - whether it's humans oppressing other humans or the natural world and other species- towards a mode of being which "attaches itself" (p. 12). Echoing the French post-structuralist philosopher Jacques Derrida, Glissant draws on the concept of the 'trace', which Derrida refers to as différance (1968), or is alterity as such. Trace is the differential, self-individuating, prelinguistic (genetic) structural condition of life itself- vegetable, animal, cultural- that precedes the very distinction between being and beings (Fritsch et al. 2018, p. 9). In other words, the trace is "that which puts us all in relation (Glissant 2020, p.9). One of Glissant's key propositions is that the rhizomic identity and associated trace thought act as a wandering that guides us, as opposed to [Western] systematic thought which isolates or elevates the 'Self' and excludes the 'other'.

For Glissant, the key principles of relation and diversity- in terms of how we perceive and relate to the 'Whole-World'don't involve mere idle speculation. Glissant alludes to a revolutionary praxis when he proclaims that they are our most powerful tools for combating global forces of oppression and exploitation, and their tendency to "reduce a place or make of it a Centre closed in on itself" (p. 109). Perhaps most importantly, this general openness to diversity, relation and the opacity of the other- what Glissant variedly terms a 'wandering' (p.33)- sparks the requisite imagination for navigating the turbulent era of the Anthropocene, wherein uncertainty abounds and horizons are continuously shifting.

\section{References}

Deleuze, G. \& Guattari, F. (1988). A thousand Plateaus: Capitalism and Schizophrenia. Bloomsbury Publishing.

Derrida, J. (1968). La diferencia (Différance). Edición electrónica de www. philosophia. cl/Escuela de Filosofía Universidad e ARCIS

Glissant, E. (2020). Treatise on the Whole-World. Liverpool University Press

Fritsch, M., Lynes, P., Wood, D., Barad, K., Clark, T. \& Colebrook, C. (2018). Eco-Deconstruction: Derrida and Environmental Philosophy. Fordham University Press.

Tampio, N. (2009). Assemblages and the multitude: Deleuze, Hardt, Negri, and the postmodern left. European Journal of Political Theory, 8(3), 383-400. 